DOI: 10.17707/AgricultForest.65.1.11

\author{
Danielle de Moraes LÚCIO, Richeliel Albert Rodrigues SILVA, \\ Kyvia Pontes Teixeira das CHAGAS, Fábio de Almeida VIEIRA ${ }^{1}$
}

\title{
BIOMETRY OF FRUITS AND SEEDS OF Hancornia speciosa Gomes (APOCYNACEAE) IN NATURAL POPULATIONS
}

\section{SUMMARY}

This study aimed verify the physical characteristics of the fruits and seeds of Hancornia speciosa in natural populations of the State of Rio Grande do Norte (RN), Brazil. The data were collected in two municipalities of the RN, Macaíba and Nísia Floresta. For the biometrics ( $n=86$ fruits and 381 seeds), fresh weight $(\mathrm{g})$, length $(\mathrm{mm})$ and diameter $(\mathrm{mm})$ were evaluated for fruits and seeds, seed number, seed thickness $(\mathrm{mm})$, yield of the pulp (\%). The biometrics data were analyzed through descriptive statistics (position and dispersion measurements). Finally, the t test was applied in order to detect differences between the averages of the biometric variables of this study and of other natural populations described in the literature. The pulp contributes on average $93.56 \%$ of the total fresh fruit mass, demonstrating high yield in the studied populations. In the comparison between the populations, it was verified that the variations in the characteristics of the mangabeira fruits are probably influenced by environmental and genetic factors, which should also be correlated in future works.

Keywords: Morphometry, Hancornia speciosa, conservation, Brazil.

\section{INTRODUCTION}

The fruits of the mangabeira (Hancornia speciosa Gomes) are used in abundance mainly in the northeast region to supply the agroindustrial sector for the production of juices, sweets, ice cream and other derivatives (Ferreira et al., 2003). The fruit has good acceptance in the market, because it produces tasty fruits and with good nutritional sources (Ferreira and Marinho, 2007). In addition to this fact, the species also has a high yield in which it is possible to select fruits with higher amounts of pulp for the industry (Gonçalves et al., 2013). Capinan (2007) argues that native fruits, such as mangaba, for example, have good nutritional sources for low-income populations living in the extractive trade as an alternative source of income.

The biometry of fruits and seeds is important to characterize the intra and interpopulational variations, allowing to infer about environmental and genetic factors that determine these divergences (Silva et al., 2007; Vieira and Carvalho,

\footnotetext{
${ }^{1}$ Danielle De Moraes Lúcio (corresponding author: danimoraesluc@ hotmail.com), Richeliel Albert Rodrigues Silva, Midwestern State University, Postgraduate Program in Forestry Sciences, Paraná, BRAZIL; Kyvia Pontes Teixeira Das Chagas, Fábio De Almeida Vieira, Federal University of Rio Grande do Norte, Postgraduate Program in Forestry Sciences, Natal, BRAZIL

Notes: The authors declare that they have no conflicts of interest. Authorship Form signed online.
} 
2009). Such information is relevant to support strategies for conservation, management of natural populations and genetic improvement.

Biometry plays an important role related to ecological aspects such as different forms of dispersion, dispersing agents, establishment of seedlings and phases of ecological succession. In addition, it contributes to the knowledge of the process of germination, viability and propagation methods (Matheus and Lopes, 2007).

The general objective of this study was to physically characterize Hancornia speciosa fruits and seeds in naturally occurring populations in the state of Rio Grande do Norte, Brazil.

\section{Area of study}

\section{MATERIAL AND METHODS}

The data were collected in two locations where the species Hancornia speciosa occurs naturally, with the purpose of capturing the variations in the species in relation to the physical characteristics of the fruits and seeds. These localities were divided and denominated in: Population Macaíba and Population Nísia Floresta. Sampling was carried out during the July 2013, a time of natural dispersion of mature fruits.

The Macaíba Population is located in the Specialized Academic Unit of Agricultural Sciences of UFRN (UAECIA), in the municipality of Macaíba, in the state of Rio Grande do Norte, approximately $26.6 \mathrm{~km}$ from the capital Natal. This area is covered by semideciduous seasonal forest and transition forest formation between Atlantic Forest and Caatinga biomes (EMPARN, 2013). The study population was divided into subpopulations. The subpopulation 1 is inserted in a forest fragment between the native vegetation and the banks of the UAECIA, whose coordinates are $5^{\circ} 53^{\prime} 21.30^{\prime \prime}$ South and 35'21'23.16" West, and elevation of $38 \mathrm{~m}$ (Figure 1A). The subpopulation 2 of collection in Macaíba, is about $740 \mathrm{~m}$ from the first collection area, in an area of native vegetation and close to pastures, between the coordinates $5^{\circ} 53^{\prime} 35.23^{\prime \prime}$ South and $35^{\circ} 21^{\prime} 02.18^{\prime \prime}$ West, and elevation of $54 \mathrm{~m}$

The Nísia Floresta Population is included in the Bonfim Guaraíra Environmental Protection Area (APA), in the municipality of Nísia Floresta, state of Rio Grande do Norte. It is an area with a natural occurrence of Hancornia speciosa and it is possible to observe the presence of communities around the fragment. In this region, there are several ecosystems, including dunes, remnants of Atlantic Forest and other associated ones (mangrove and coastal board) (MMA, 2012), whose coordinates of the study area are 5 58'23.50" South and $35^{\circ} 11^{\prime} 51.34$ " West, and elevation of $32 \mathrm{~m}$. The municipality of Nísia Floresta is approximately $40.1 \mathrm{~km}$ from the capital Natal, traveling by BR-101.

Macaíba and Nísia Floresta are municipalities that participate in the metropolitan region of Natal (capital of the RN). They present climatic classification according to Köppen, type As', of tropical climate with dry summer and rainy season. It has an annual rainfall of $1,442.8 \mathrm{~mm}$, average temperature of 
$27.1{ }^{\circ} \mathrm{C}$ and average annual relative humidity around 76\% (MME, 2005a); (MME, 2005b).

\section{Sampling}

The fruit sampling was carried out in two natural populations of the State of Rio Grande do Norte, in order to capture the variations in the species regarding the physical characteristics of the fruits and seeds. Sampling was carried out during July 2013, a time of natural dispersion of mature fruits.

At the total, 86 mature fruits of Hancornia speciosa were collected directly from the ground, under the matrices. The sampling used was simple random (where each element of the population has the same probability of being sampled), comprising 6 matrices. The mean size of the sampled trees was $3.06 \mathrm{~m}$ in height and $7.0 \mathrm{~cm}$ in diameter at chest height. After being collected, the fruits were sent to the Laboratory of Genetics and Forest Improvement of UFRN to begin the biometric analysis, discarding those that showed visible physical damages and rot.

The biometric characteristics were: fresh mass $(\mathrm{g})$, length $(\mathrm{mm})$ and diameter $(\mathrm{mm})$ of fruits and seeds. The dimensions were determined with the aid of a digital caliper and the fresh mass was determined from a precision analytical balance. In order to determine the seed size, after being measured, the fruits were manually pulped. The excess pulp surrounding the seeds was withdrawn with the aid of a stylet and, subsequently, the seeds were washed in running water. In addition, the number of seeds (unity), seed thickness $(\mathrm{mm})$ and yield of the pulp (YP) (\%), obtained from the formula proposed by Freitas et al. (2012), where: YP $=\mathrm{MP} \times 100 \mathrm{MF}$. The mass of the pulp $(\mathrm{MP})$ was determined by subtracting the fresh mass of the whole fruit (MF) by the fresh mass of the seeds.

\section{Statistical analysis}

The biometric data were analyzed using the statistical software BIOESTAT version 5.3 (Ayres et al., 2007). For each variable were calculated: arithmetic mean, standard deviation, standard error, coefficient of variation $(C V)$, asymmetry $(S)$ and kurtosis $(K)$. The distribution was considered asymmetric on the left when the values of $S<0$; and asymmetric distribution on the right when the values have $S>0$. The reference values for the kurtosis coefficient $(K)$ were $K>3$ for sharp distribution in relation to the normal (leptokurtic) curve. For $\mathrm{K}<$ 3 , the distribution was considered flatter than the normal (platicurtic) curve, according to Silva et al. (2007).

To determine if the data are statistically different from the normal distribution, the fruit and seed variables were submitted to the normality test of Lilliefors. After detecting that the data had a curve different from normal $(P<$ 0.05 ), the use of non-parametric statistics was considered. Thus, the Spearman correlation coefficient $\left(r_{s}\right)$ was calculated using the STATISTICA 7 program (Statsoft, 2004). In addition, the Student $t$ test was applied in order to know how 
much the values of the populations raised in this study are significantly similar to that of a distinct population mentioned in the literature.

The Student's t-test of this study was based on two independent samples, when only the means, variances and sample sizes of each population were available. The analyzes were performed using the BIOESTAT program version 5.3 (Ayres et al., 2007), following the following hypotheses: $\mathrm{H}_{0}$ (null hypothesis): There are no differences between the means of the individuals of the populations sampled: $\mu_{1}=\mu_{2} \cdot \mathrm{H}_{1}$ (alternative hypothesis): There is difference between the means of the individuals of the populations sampled: $\mu_{1} \neq \mu_{2}$.

\section{RESULTS AND DISCUSSION}

In Table 1, the results can be observed, including position and dispersion measurements for each biometric variable that was evaluated.

Table 1. Biometric characteristics of fruits and seeds of Hancornia speciosa.

\begin{tabular}{cccccccc}
\hline Biometric Features & $n$ & Max Min & $\begin{array}{c}\text { Mean } \pm \text { standard } \\
\text { error }\end{array}$ & $C V(\%)$ & $S$ & $K$ \\
\hline FRUITS & & & & & & \\
\hline Fresh mass (g) & 86 & 56.56 & 2.07 & $13.86 \pm 1.13$ & 76.00 & 1.87 & 4.30 \\
Lenght (mm) & 86 & 48.1016 .80 & $28.32 \pm 0.71$ & 23.39 & 0.50 & 0.07 \\
Diameter (mm) & 86 & 45.8016 .60 & $26.24 \pm 0.70$ & 24.82 & 0.76 & 0.33 \\
Number of seeds (unity) & 66 & 32.00 & 1.00 & $5.77 \pm 0.70$ & 99.01 & 2.40 & 8.00 \\
Yield of the pulp (\%) & 63 & 99.9560 .90 & $93.56 \pm 0.83$ & 7.02 & -3.50 & 13.51 \\
\hline SEEDS & & & & & & \\
\hline Fresh mass (g) & 381 & 1.67 & 0.01 & $0.23 \pm 0.01$ & 121.54 & 3.80 & 14.85 \\
Length (mm) & 381 & 16.60 & 4.80 & $10.47 \pm 0.08$ & 14.23 & -0.43 & 1.17 \\
Diameter (mm) & 381 & 10.603 .10 & $8.18 \pm 0.06$ & 14.12 & -0.85 & 1.95 \\
Thickness (mm) & 381 & 4.50 & 0.30 & $3.01 \pm 0.03$ & 20.72 & -1.23 & 2.97 \\
\hline
\end{tabular}

$*_{n}$ : sample size, $C V$ : coefficient of variation, $S$ : asymmetry, $K$ : kurtosis, Max: Maximum, Min: Minimum.

There was considerable variation in the amplitude (maximum and minimum values) of the biometric characteristics of the fruits. The arithmetic mean of the fresh fruit mass was $13.86 \mathrm{~g}$. Capinan (2007) presented the following average values for fresh mass of mangabeira fruits in three municipalities of the state of Bahia: $22.61 \mathrm{~g}$ in Conde (north coast); $10.39 \mathrm{~g}$ in Nova Soure (semi-arid) and $13.05 \mathrm{~g}$ in Ouriçangas (agreste). It is possible to affirm that, according to the biometric characteristics evaluated in the $\mathrm{RN}$ state region, there are similarities with the values found in the Bahia region by Capinan (2007), mainly with the fruits of the wild population. It is known that variations in fruit characteristics are also influenced by environmental factors, such as the availability of water, which is an essential factor for the production of fleshy fruits (Tabarelli et al., 2003), and consequently reflects in the total fresh mass of the fruits. 
As for the fruit length, the mean was $28.32 \mathrm{~mm}$. This result is close to that found by Alves et al. (2010), which evaluated five genotypes from the Piauí semi-arid region and obtained averages between $27.64 \mathrm{~mm}$ and $29.08 \mathrm{~mm}$. In this comparison, the authors found no significant statistical difference between the genotypes. In the present work, the average fruit diameter was $26.24 \mathrm{~mm}$, the parameter in which it did not present greater differences than those found by Capinan (2007): $34.49 \mathrm{~mm} ; 26.87 \mathrm{~mm}$ and $30.74 \mathrm{~mm}$ in three populations in Bahia. The mean number of seeds per fruit was 5.77. Capinan (2007) obtained the following values: 14.95 for the municipality of Conde; 6.23 for the municipality of Nova Soure and 9.98 for the municipality of Ouriçangas. These differences suggest that the mean number of seeds per fruit is probably not influenced by the environment, but is determined by the biological potential of the species for seed production (Carvalho et al., 1997). In addition, no significant correlations were observed between fruit size and number of seeds, as can be observed in Table 2.

Table 2. Spearman correlation $\left(r_{s}\right)$ between the biometric variables of the fruits and seeds of Hancornia speciosa.

\begin{tabular}{lc}
\hline Correlations & $r_{S}$ \\
\hline Fruits & $0,600^{*}$ \\
\hline Fresh mass x Length of the fruit & $0,445^{*}$ \\
Fresh mass x Diameter of the fruit & $0,396^{*}$ \\
Length x Diameter of the fruit & $0,131^{\mathrm{ns}} / 0,068^{\mathrm{ns}}$ \\
Mass / Diameter of the fruit x Number of Seeds & $-0,006^{\mathrm{ns}} / 300^{*}$ \\
Fresh mass x Yield of the pulp & $-0,425^{*}$ \\
Number of seeds x Yield of the pulp & \\
\hline Seeds & $0,637^{*}$ \\
\hline Fresh mass x Seeds length & $0,576^{*}$ \\
Fresh mass x Seeds diameter & $0,464^{*}$ \\
Fresh mass x Seeds thickness & $0,716^{*}$ \\
Seeds Length x Diameter & $0,261^{*}$ \\
Seeds Length x thickness & $0,211^{*}$ \\
Seeds Diameter x thickness & $-0,620^{*}$ \\
Fresh mass x Yield of the pulp & \\
\hline
\end{tabular}

$*=\mathrm{P}<0.05 ; \mathrm{ns}=$ not significant.

Zuffo et al. (2012) evaluated the biometric characteristics of the mango seeds and obtained the following means: $9.43 \mathrm{~mm}$ long, $3.42 \mathrm{~mm}$ thick and 7.35 $\mathrm{mm}$ diameter, values close to those found in this study. This phenotypic similarity indicates that the biometric characterization of the seeds can be applied as an important tool in the taxonomy and identification of varieties. In summary, the biometric variables analyzed do not present significant differences with other studies carried out in natural populations of the Northeast. 
Capinan (2007) obtained $82.58 \%$ yield of the pulp in a sample from the municipality of Conde, on the North coast of the state of Bahia; lower than that found in this study, which was $93.56 \%$. It can be affirmed that most of the fruit is constituted by the pulp, being thus, a species with great use for its diverse means of consumption.

The standard error for all evaluated fruit characteristics was low, demonstrating that the sample effort was expressive for the entire population (Table 1). Regarding the coefficient of variation $(C V)$, the values of length, fruit diameter and yield of the pulp had little variation. On the other hand, the variables fresh mass of the fruits and the number of seeds presented high $C V$, indicating high variability. Among the biometric characteristics of the seeds, a high coefficient of variation was observed for the fresh mass when compared to the other characteristics analyzed.

The biometric characteristics of the fruits were positive with respect to the asymmetry $(S)$, indicating asymmetric behavior to the right, thus, fruits with lower fresh mass, length and diameter predominated in the analyzed sample, except for the yield of the pulp value. Unlike the fruits, the seeds had an asymmetric distribution to the left and negative, evidencing the predominance of seeds with greater length, diameter and thickness in the analyzed sample, except for the value of fresh seed mass.

Regarding the kurtosis coefficient, the values of fresh fruit mass, number of seeds, yield of the pulp and fresh seed mass were $K>3$, that is, leptokurtic, indicating that there is a large concentration of the values around the mean. As for the variables length, fruit and seed diameter and seed thickness, the distribution was more flattened than the normal, therefore, platicurtic $(K<3)$ curve, indicating dispersion of the data around the mean.

According to Spearman's correlation, only the values between the mass / length / diameter of the fruit and the number of seeds were not significant (Table 2 ). The correlations between the variables fresh mass $x$ fruit length and fresh mass $\mathrm{x}$ diameter were positive and significant, demonstrating that larger fruits also have greater mass. In addition, it was found that fruits with greater length have larger diameter, demonstrating the circular (rounded) shape of the fruit.

There was a significant and positive correlation $(P<0.05)$ for all evaluated parameters related to the seeds. The correlation between the length and diameter of the seeds presented a higher value in relation to the other correlated parameters. Despite the lower correlation value between seed diameter and seed thickness, it was observed that the correlation was significant and positive. This suggests that larger seeds have little gain in thickness.

Positive and significant correlations were observed for the relationship between fresh fruit mass and yield of the pulp, confirming the hypothesis that fruits with higher fresh mass are directly related to fruits with higher pulp content. Although this relationship is apparently logical, it was found that fruits with higher number of seeds have a lower yield $\left(r_{s}=-0.425\right)$. In this case, the greater fresh mass of the fruit is due to the greater number or mass of the seeds, 
resulting in the lower yield of the pulp. Specifically, negative and significant correlations were observed between the number of seeds $\mathrm{x}$ yield of the pulp and between the fresh mass of the seeds $x$ yield of the pulp, because in fruits with higher yield of the pulp the seeds contribute less with the total mass of the fruits (Table 2).

Biometry studies of fruits and seeds subsidize information relevant to the conservation of species. Thus, as studies for Hancornia speciosa are still scarce, such information may support the programs of genetic conservation of natural populations and breeding of the species.

In this sense, it is also necessary to quantify the variations between populations. For this, Student's t test allows the comparison of the means of two independent groups and it does not require the same sample size. It has the purpose of analyzing statistically the variations occurred in the two samplings. For the physical characteristics of mangabeira, for the most part, there were no significant differences between populations, both for the Macaíba (Table 3) and Nísia Floresta populations (Table 4).

There is a trend towards significant statistical differences mainly related to the municipality of Nova Xavantina (MT) in the Cerrado biome, compared to the populations of this study (Macaíba and Nísia Floresta). Ganga et al. (2010) affirm that the speciosa botanical variety occurs in a generalized way in the Northeast region and presently in the work, it shows a table with the localities and the respective botanical varieties sampled in the Cerrado, where speciosa variety is less common. The municipalities sampled in the state of Mato Grosso, the varieties are mostly: gardneri and cuyabensis. With this, this statistical divergence can be justified by the different botanical varieties among the comparative localities. These authors also affirm that there is great phenotypic variation between populations sampled and also within the botanical varieties.

Moura et al. (2008), by analyzing the genetic variability by RAPD (Random DNA Amplified DNA Polymorphism) between the speciosa variety and the pubescens and gardinerii varieties, found $90.70 \%$ genetic variability within the studied varieties, $4.59 \%$ between subpopulations and $4.71 \%$ among varieties within subpopulations. These variations are, according to the authors, due to the restriction of gene flow among mangabeira varieties, probably determined by the behavior of the pollinating agent, the lack of synchronism in the flowering, the population density and the location of the individuals within the subpopulation.

The comparisons between the values for fresh fruit mass, in general, were not significant. However, significant values were discarded when comparing the means between the municipalities of Macaíba (RN) and Nova Xavantina (MT), according to Table 3; and between Nísia Floresta (RN) and Conde (BA) and Nísia Floresta (RN) and Nova Xavantina (MT), according to Table 4. 
Table 3. " $\mathrm{t}$ " test comparing the biometric variables of the fruits of Hancornia speciosa among the population Macaíba and other regions.

\begin{tabular}{|c|c|}
\hline Comparisons & $\mathrm{t}$ \\
\hline \multicolumn{2}{|l|}{ Fresh mass $(\mathrm{g})$} \\
\hline Macaíba (RN) ${ }^{a} x$ Conde $(B A)^{b}$ & $-2,93^{\mathrm{ns}}$ \\
\hline Macaíba $(\mathrm{RN})^{\mathrm{a}} x$ Nova Soure $(\mathrm{BA})^{\mathrm{b}}$ & 1,91 ns \\
\hline Macaíba (RN) ${ }^{a} x$ Ouriçangas (BA) ${ }^{\mathrm{b}}$ & $0,86^{\mathrm{ns}}$ \\
\hline Macaíba $(\mathrm{RN})^{\mathrm{a}} x$ Nova Xavantina $(\mathrm{MT})^{\mathrm{c}}$ & $-8,79 *$ \\
\hline Macaíba $(R N)^{a} x$ Nísia Floresta $(R N)^{d}$ & $-0,11^{\mathrm{ns}}$ \\
\hline Macaíba $(\mathrm{RN})^{\mathrm{a}} x$ Ipojuca $(\mathrm{PE})^{\mathrm{d}}$ & $0,80^{\mathrm{ns}}$ \\
\hline Macaíba $(\mathrm{RN})^{\text {a }} x$ Parnamirim $(\mathrm{RN})^{\mathrm{d}}$ & $1,01^{\mathrm{ns}}$ \\
\hline Macaíba $(\mathrm{RN})^{\text {a }} x$ Extremoz $(\mathrm{RN})^{\mathrm{d}}$ & $0,33^{\text {ns }}$ \\
\hline Macaíba $(\mathrm{RN})^{\mathrm{a}} x$ Rio Tinto $(\mathrm{PE})^{\mathrm{d}}$ & $0,18^{\mathrm{ns}}$ \\
\hline \multicolumn{2}{|l|}{ Lenght (mm) } \\
\hline Macaíba (RN) ${ }^{a} x$ Conde $(B A)^{b}$ & $-5,25^{*}$ \\
\hline Macaíba $(\mathrm{RN})^{\mathrm{a}} x$ Nova Soure $(\mathrm{BA})^{\mathrm{b}}$ & $-2,16^{\mathrm{ns}}$ \\
\hline Macaíba (RN) ${ }^{\text {a }} x$ Ouriçangas $(\mathrm{BA})^{\mathrm{b}}$ & $-4,52 *$ \\
\hline Macaíba $(\mathrm{RN})^{\mathrm{a}} x$ Nova Xavantina $(\mathrm{MT})^{\mathrm{c}}$ & $-11,99 *$ \\
\hline Macaíba $(\mathrm{RN})^{\text {a }} x$ Nísia Floresta $(\mathrm{RN})^{\mathrm{d}}$ & $-4,39^{\text {ns }}$ \\
\hline Macaíba (RN) ${ }^{\text {a }} x$ Ipojuca $(\mathrm{PE})^{\mathrm{d}}$ & $-2,25$ ns \\
\hline Macaíba $(\mathrm{RN})^{\text {a }} x$ Parnamirim $(\mathrm{RN})^{\mathrm{d}}$ & $-2,72^{\mathrm{ns}}$ \\
\hline Macaíba $(\mathrm{RN})^{\text {a }} x$ Extremoz $(\mathrm{RN})^{\mathrm{d}}$ & $-2,59^{\mathrm{ns}}$ \\
\hline Macaíba (RN) ${ }^{a} x$ Rio Tinto (PE) ${ }^{d}$ & $7,97 *$ \\
\hline \multicolumn{2}{|l|}{ Diameter $(\mathrm{mm})$} \\
\hline Macaíba $(\mathrm{RN})^{\mathrm{a}} x$ Conde $(\mathrm{BA})^{\mathrm{b}}$ & $-7.56^{*}$ \\
\hline Macaíba $(\mathrm{RN})^{\mathrm{a}} x$ Nova Soure $(\mathrm{BA})^{\mathrm{b}}$ & $0,19^{\text {ns }}$ \\
\hline Macaíba $(\mathrm{RN})^{\mathrm{a}} x$ Ouriçangas $(\mathrm{BA})^{\mathrm{b}}$ & $-2,31 \mathrm{~ns}$ \\
\hline Macaíba $(\mathrm{RN})^{\mathrm{a}} x$ Nova Xavantina $(\mathrm{MT})^{\mathrm{c}}$ & $-11,59 *$ \\
\hline Macaíba (RN) ${ }^{a} x$ Nísia Floresta $(R N)^{d}$ & $-6,19 *$ \\
\hline Macaíba $(\mathrm{RN})^{\mathrm{a}} x$ Ipojuca $(\mathrm{PE})^{\mathrm{d}}$ & $0,19^{\text {ns }}$ \\
\hline Macaíba $(\mathrm{RN})^{\text {a }} x$ Parnamirim $(\mathrm{RN})^{\mathrm{d}}$ & $0,62^{\mathrm{ns}}$ \\
\hline Macaíba $(\mathrm{RN})^{\text {a }} x$ Extremoz $(\mathrm{RN})^{\mathrm{d}}$ & $-0,17$ ns \\
\hline Macaíba (RN) a $x$ Rio Tinto (PE) ${ }^{d}$ & $0,55^{\mathrm{ns}}$ \\
\hline \multicolumn{2}{|l|}{ Number of seeds (unity) } \\
\hline Macaíba (RN) ${ }^{\mathrm{a}} x$ Conde $(\mathrm{BA})^{\mathrm{b}}$ & $-6,97 *$ \\
\hline Macaíba (RN) a $x$ Nova Soure (BA) ${ }^{b}$ & $-0,01^{\mathrm{ns}}$ \\
\hline Macaíba $(\mathrm{RN})^{\mathrm{a}} x$ Ouriçangas $(\mathrm{BA})^{\mathrm{b}}$ & $-2,95$ ns \\
\hline Macaíba $(\mathrm{RN})^{\text {a }} x$ Nova Xavantina $(\mathrm{MT})^{\mathrm{c}}$ & $-8,63 *$ \\
\hline \multicolumn{2}{|l|}{ Yield of the pulp $(\%)$} \\
\hline Macaíba (RN) ${ }^{\mathrm{a}} x$ Conde $(\mathrm{BA})^{\mathrm{b}}$ & $6,51 *$ \\
\hline Macaíba $(\mathrm{RN})^{\mathrm{a}} x$ Nova Soure $(\mathrm{BA})^{\mathrm{b}}$ & $5,68^{*}$ \\
\hline Macaíba $(\mathrm{RN})^{\mathrm{a}} x$ Ouricangas $(\mathrm{BA})^{\mathrm{b}}$ & 3,93 ns \\
\hline Macaíba $(\mathrm{RN})^{\mathrm{a}} x$ Nísia Floresta $(\mathrm{RN})^{\mathrm{d}}$ & 2,04 ns \\
\hline Macaíba $(\mathrm{RN})^{\text {a }} x$ Ipojuca $(\mathrm{PE})^{\mathrm{d}}$ & $3,60^{\mathrm{ns}}$ \\
\hline Macaíba $(\mathrm{RN})^{\text {a }} x$ Parnamirim $(\mathrm{RN})^{\mathrm{d}}$ & $1,11^{\mathrm{ns}}$ \\
\hline Macaíba (RN) a $x$ Extremoz $(R N)^{d}$ & $1,41^{\mathrm{ns}}$ \\
\hline Macaíba (RN) a $x$ Rio Tinto (PE) ${ }^{\mathrm{d}}$ & $2,40^{\mathrm{ns}}$ \\
\hline
\end{tabular}

$*=P<0.05 ;$ ns $=$ not significant.

Where: ${ }^{\mathrm{a}}=$ this study; ${ }^{\mathrm{b}}=$ Capinan $(2007) ;{ }^{\mathrm{c}}=$ Gonçalves et al. $(2013) ;{ }^{\mathrm{d}}=$ Araújo et al. (2003). 
Table 4. " $t$ " test comparing the biometric variables of the fruits of Hancornia speciosa among the population of Nísia Floresta and other regions.

\begin{tabular}{|c|c|}
\hline Comparisons & $\mathrm{t}$ \\
\hline \multicolumn{2}{|l|}{ Fresh mass (g) } \\
\hline Nísia Floresta $(\mathrm{RN})^{\mathrm{a}} x$ Conde $(\mathrm{BA})^{\mathrm{b}}$ & $-6,59 *$ \\
\hline Nísia Floresta $(\mathrm{RN})^{\mathrm{a}} x$ Nova Soure $(\mathrm{BA})^{\mathrm{b}}$ & $1,97^{\mathrm{ns}}$ \\
\hline Nísia Floresta $(\mathrm{RN})^{\mathrm{a}} x$ Ouriçangas $(\mathrm{BA})^{\mathrm{b}}$ & $0,13^{\mathrm{ns}}$ \\
\hline 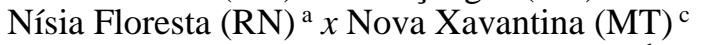 & $-13,65^{*}$ \\
\hline Nísia Floresta $(\mathrm{RN})^{\mathrm{a}} x$ Nísia Floresta $(\mathrm{RN})^{\mathrm{d}}$ & $-1,46^{\mathrm{ns}}$ \\
\hline Nísia Floresta $(\mathrm{RN})^{\mathrm{a}} x$ Ipojuca $(\mathrm{PE})^{\mathrm{d}}$ & $0,02^{\mathrm{ns}}$ \\
\hline Nísia Floresta $(\mathrm{RN})^{\mathrm{a}} x$ Parnamirim $(\mathrm{RN})^{\mathrm{d}}$ & $0,38^{\mathrm{ns}}$ \\
\hline Nísia Floresta $(\mathrm{RN})^{\mathrm{a}} x$ Extremoz $(\mathrm{RN})^{\mathrm{d}}$ & $-0,79^{\mathrm{ns}}$ \\
\hline Nísia Floresta $(\mathrm{RN})^{\mathrm{a}} x$ Rio Tinto $(\mathrm{PE})^{\mathrm{d}}$ & $-0,95^{\mathrm{ns}}$ \\
\hline \multicolumn{2}{|l|}{ Lenght (mm) } \\
\hline Nísia Floresta $(\mathrm{RN})^{\mathrm{a}} x$ Conde $(\mathrm{BA})^{\mathrm{b}}$ & $-10,17^{*}$ \\
\hline Nísia Floresta $(\mathrm{RN})^{\mathrm{a}} x$ Nova Soure $(\mathrm{BA})^{\mathrm{b}}$ & $-4,80^{*}$ \\
\hline Nísia Floresta $(\mathrm{RN})^{\mathrm{a}} x$ Ouriçangas $(\mathrm{BA})^{\mathrm{b}}$ & $-7,09^{*}$ \\
\hline Nísia Floresta $(\mathrm{RN})^{\mathrm{a}} x$ Nova Xavantina $(\mathrm{MT})^{\mathrm{c}}$ & $-18,15^{*}$ \\
\hline Nísia Floresta $(R N)^{\text {a }} x$ Nísia Floresta $(R N)^{\text {d }}$ & $-9,77^{\mathrm{ns}}$ \\
\hline Nísia Floresta $(\mathrm{RN})^{\mathrm{a}} x$ Ipojuca $(\mathrm{PE})^{\mathrm{d}}$ & $-5,73 *$ \\
\hline Nísia Floresta $(\mathrm{RN})^{\mathrm{a}} x$ Parnamirim $(\mathrm{RN})^{\mathrm{d}}$ & $-6,62 *$ \\
\hline Nísia Floresta $(\mathrm{RN})^{\mathrm{a}} x$ Extremoz $(\mathrm{RN})^{\mathrm{d}}$ & $-6,35^{*}$ \\
\hline Nísia Floresta $(\mathrm{RN})^{\mathrm{a}} x$ Rio Tinto $(\mathrm{PE})^{\mathrm{d}}$ & $-6,13 *$ \\
\hline \multicolumn{2}{|l|}{ Diameter $(\mathrm{mm})$} \\
\hline Nísia Floresta $(\mathrm{RN})^{\mathrm{a}} x$ Conde $(\mathrm{BA})^{\mathrm{b}}$ & $-6,83^{*}$ \\
\hline Nísia Floresta $(\mathrm{RN})^{\mathrm{a}} x$ Nova Soure $(\mathrm{BA})^{\mathrm{b}}$ & $-0,84^{\mathrm{ns}}$ \\
\hline Nísia Floresta $(\mathrm{RN})^{\mathrm{a}} x$ Ouriçangas $(\mathrm{BA})^{\mathrm{b}}$ & $-3,88^{\text {ns }}$ \\
\hline Nísia Floresta $(\mathrm{RN})^{\mathrm{a}} x$ Nova Xavantina $(\mathrm{MT})^{\mathrm{c}}$ & $-17,07 *$ \\
\hline Nísia Floresta $(R N)^{\mathrm{a}} x$ Nísia Floresta $(\mathrm{RN})^{\mathrm{d}}$ & $-1,58^{\mathrm{ns}}$ \\
\hline Nísia Floresta $(\mathrm{RN})^{\mathrm{a}} x$ Ipojuca $(\mathrm{PE})^{\mathrm{d}}$ & $-1,33^{\mathrm{ns}}$ \\
\hline Nísia Floresta $(\mathrm{RN})^{\mathrm{a}} x$ Parnamirim $(\mathrm{RN})^{\mathrm{d}}$ & $-0,59^{\mathrm{ns}}$ \\
\hline Nísia Floresta $(\mathrm{RN})^{\mathrm{a}} x$ Extremoz $(\mathrm{RN})^{\mathrm{d}}$ & $-1,95^{\mathrm{ns}}$ \\
\hline Nísia Floresta (RN) ${ }^{a} x$ Rio Tinto $(\mathrm{PE})^{\mathrm{d}}$ & $-0,72^{\mathrm{ns}}$ \\
\hline \multicolumn{2}{|l|}{ Number of seeds (unity) } \\
\hline Nísia Floresta $(\mathrm{RN})^{\mathrm{a}} x$ Conde $(\mathrm{BA})^{\mathrm{b}}$ & $-8,16^{*}$ \\
\hline Nísia Floresta $(\mathrm{RN})^{\mathrm{a}} x$ Nova Soure $(\mathrm{BA})^{\mathrm{b}}$ & $-0,67^{\mathrm{ns}}$ \\
\hline Nísia Floresta $(\mathrm{RN})^{\mathrm{a}} x$ Ouriçangas $(\mathrm{BA})^{\mathrm{b}}$ & $-3,85^{\mathrm{ns}}$ \\
\hline Nísia Floresta $(\mathrm{RN})^{\mathrm{a}} x$ Nova Xavantina $(\mathrm{MT})^{\mathrm{c}}$ & $-12,74 *$ \\
\hline \multicolumn{2}{|l|}{ Yield of the pulp (\%) } \\
\hline Nísia Floresta $(\mathrm{RN})^{\mathrm{a}} x$ Conde $(\mathrm{BA})^{\mathrm{b}}$ & $9,48^{*}$ \\
\hline Nísia Floresta $(\mathrm{RN})^{\mathrm{a}} x$ Nova Soure $(\mathrm{BA})^{\mathrm{b}}$ & $7,65^{*}$ \\
\hline Nísia Floresta $(\mathrm{RN})^{\mathrm{a}} x$ Ouriçangas $(\mathrm{BA})^{\mathrm{b}}$ & $5,23 *$ \\
\hline Nísia Floresta $(R N)^{\mathrm{a}} x$ Nísia Floresta $(\mathrm{RN})^{\mathrm{d}}$ & $3,74^{\mathrm{ns}}$ \\
\hline Nísia Floresta $(\mathrm{RN})^{\mathrm{a}} x$ Ipojuca $(\mathrm{PE})^{\mathrm{d}}$ & $5,87 *$ \\
\hline Nísia Floresta $(\mathrm{RN})^{\mathrm{a}} x$ Parnamirim $(\mathrm{RN})^{\mathrm{d}}$ & $2,43^{\mathrm{ns}}$ \\
\hline Nísia Floresta $(\mathrm{RN})^{\mathrm{a}} x$ Extremoz $(\mathrm{RN})^{\mathrm{d}}$ & $2,86^{\mathrm{ns}}$ \\
\hline 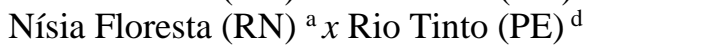 & $4,26^{\mathrm{ns}}$ \\
\hline
\end{tabular}

$*=P<0.05 ; \mathrm{ns}=$ not significant.

Where: ${ }^{\mathrm{a}}=$ this study; ${ }^{\mathrm{b}}=$ Capinan (2007); ${ }^{\mathrm{c}}=$ Gonçalves et al. (2013); ${ }^{\mathrm{d}}=$ Araújo et al. (2003). 
For the variable fruit length, Conde and Ouriçangas, the municipalities pertaining to the state of Bahia, presented divergent and significant means when compared to Macaíba/RN and Nísia Floresta/RN (Table 3 and Table 4). This divergence also occurred in the comparison between the means of Nísia Floresta/RN and Nova Soure/BA (Table 4). Capinan (2007) studied the genetic variation within and among these three populations of Bahia and detected that there is greater intrapopulational genetic variation than the interpopulational variation, through RAPD marker. According to the results of the author, one should consider the main methods that evaluate genetic divergence among the populations of Bahia are fruit mass and diameter. The author also suggests studies of breeding of the species aiming at exploitation in the industrial market.

Ganga et al. (2010) found high levels of phenotypic variation for the biometric characteristics of the fruits among natural populations of mangabeira in the Cerrado. In fact, phenotypic variations among populations, such as fruit mass and yield of the pulp, are influenced by environmental factors, such as water availability, which is essential for fruit production with succulent mesocarp (Tabarelli et al., 2003). This variation can be even more significant considering the high variability in fruit size of this species. In addition, it can be determined by uncontrolled environmental conditions, such as anthropization, soil and climate.

Due to the phenotypic variability of this species, regardless of the geographic distribution, there are difficulties in the production and subsequent commercialization of the fruits, since it does not meet the income demanded by the market. This may compromise the production of species such as mangabeira in the long term, once it is important to select and multiply individuals that produce quality fruits. In this case, studies of physical and chemical characterization of fruits are necessary to direct breeding programs. Furthermore, the variability of genetic origin, which is passed on to each generation, is important for maintaining the evolutionary potential of the species and it must be conserved in the natural populations.

Finally, it is possible to affirm that most of the means for the sampled populations agree with the null hypothesis, which says that there are no differences in the pairwise comparison with the means of other populations published in the literature. However, in the same way, significant differences were found in the populations sampled, mainly because there are environmental or genetic influences in the populations, thus they agree with the alternative hypothesis.

\section{CONCLUSIONS}

The study carried out with the populations of Hancornia speciosa in the state of Rio Grande do Norte has reached the following conclusions:

Larger fruits present a higher amount of pulp, which contributes on average with $93.56 \%$ of the total fresh fruit mass, demonstrating high yield in the studied populations. 
There is potential for conservation and genetic improvement of the species, since the coefficient of variation of fresh fruit mass was high (76\%), representing considerable intrapopulation variability.

There are statistical differences between the populations of this study (Macaíba and Nísia Floresta) mainly when compared to the municipality of Nova Xavantina (MT), due to the differences between the botanical varieties found in different regions of the country.

Environmental and genetic variations are the main factors attributed to phenotypic (morphological) differences within and among mangabeira populations, which should be investigated in future work.

\section{ACKNOWLEDGMENTS}

This study was financed in part by the Coordenação de Aperfeiçoamento de Pessoal de Nível Superior - Brasil (CAPES) - Finance Code 001

\section{REFERENCES}

Alves, T. De A.; Alves, R. E.; Moura, C. F. H.; Silveira, R. S. Da; Figueiredo, R. W. de. Características físicas de frutos da mangabeira (Hancornia speciosa Gomes) nativos do semi-árido piauiense. In: CONGRESSO BRASILEIRO DE FRUTICULTURA, 21., 2010, Natal. Anais... Natal: Sociedade Brasileira de Fruticultura, 2010.

Araújo, I. A. De; Ferreira, E. G.; Soares, K. T; Fontinélli, I. S. C. Características Físicas de Frutos da Mangabeira (Hancornia speciosa Gomes) Cultivada na Zona da Mata Paraibana. In: SIMPÓSIO BRASILEIRO SOBRE A CULTURA DA MANGABA, 1., 2003, Aracaju. Anais do Simpósio Brasileiro sobre a Cultura da Mangaba. Aracaju: Embrapa Semiárido, 2003. p. 1 - 3. CD-ROM.

Ayres, M. Et Al. BioEstat: aplicações estatísticas nas áreas de ciências biométricas. Versão 5.0. Belém: Sociedade Civil Mamirauá, MCT-CNPq, 2007.

Capinan, G. C. S. Seleção de germoplasma de mangabeira (Hancornia speciosa) definidos por marcadores morfológicos e moleculares. 2007. 98 f. Dissertação de mestrado - Univesidade Federal do Recôncavo da Bahia, Cruz Das Almas, 2007.

Carvalho, M. R. T. De; Bordignon, R.; Ballvé, R. M. L.; Pinto-Maglio, C. A. F.; Filho, H. P. M. Aspectos biológicos do reduzido número de sementes da tangerina 'sunki'. Bragantia, v. 56, p. 69-77, 1997.

EMPARN. Empresa de Pesquisa Agropecuária do Rio Grande do Norte. Disponível em: <www.emparn.rn.gov.br>. Acesso em: 20 ago. 2013.

Ferreira, E. G.; Marinho, S. J. O. Produção de frutos da mangabeira para consumo in natura e industrialização. Revista Tecnologia \& Ciência Agropecuária, João Pessoa, v. 1, n. 1, p.9-14, set. 2007.

Ferreira, E. G.; Santos, E. S. Dos; Araújo, I. A. De. Avaliações biométricas de plantas e físico-químicas de frutos de mangabeira de pomares nativo e cultivado. In: I SIMPÓSIO BRASILEIRO SOBRE A CULTURA DA MANGABA, 2003, Aracaju. Embrapa Semi-árido. Aracaju, 2003.

Freitas, M. K. C. De; Coimbra, R. R, Aguiar, G. B.; Aguiar, C. B. N.; Chagas, D. B. Das; Ferreira, W. M.; Oliveira, R. J. Variabilidade fenotípica e caracterização morfológica de uma população natural de Hancornia speciosa Gomes. Bioscience Journal, Uberlândia, v. 28, n. 5, p. 833-841. out. 2012.

Ganga, R. M. D.; Ferreira, G. A.; Chaves, L. J; Naves, R. V.; Nascimento, J. L. do. Caracterização de frutos e árvores de populações naturais de Hancornia speciosa 
Gomes do Cerrado. Revista Brasileira de Fruticultura, Jaboticabal, v. 32, n. 1, p.101-113, mar. 2010.

Gonçalves, L. G. V.; Andrade, F. R.; Marimon Junior, B. H.; Schossler, T. R.; Lenza, E.; Marimon, B. S. Biometria de frutos e sementes de mangaba (Hancornia speciosa Gomes) em vegetação natural na região leste de Mato Grosso, Brasil. Revista de Ciências Agrárias, [s.1], v. 36, n. 1, p.31-40, 2013.

Matheus, M. T.; Lopes, J. C. Morfologia de frutos, sementes e plântulas e germinação de sementes de Erythrina variegata L. Revista Brasileira de Sementes, v. 29, n. 3, p. 08-17, 2007.

MMA - MINISTÉRIO DO MEIO AMBIENTE (Nísia Floresta). Plano de Manejo da Floresta Nacional de Nísia Floresta, Rio Grande do Norte. Nísia Floresta: Ministério do Meio Ambiente, 2012. 48 p.

MME - MINISTÉRIO DE MINAS E ENERGIA (Recife). Serviço Geológico do Brasil CPRM. Projeto cadastro de fontes de abastecimento por água subterrânea: Diagnóstico do município de Macaíba. Recife: Ministério de Minas e Energia, 2005a. 25 p.

MME - MINISTERIO DE MINAS E ENERGIA (Recife). Serviço Geológico do Brasil CPRM. Projeto cadastro de fontes de abastecimento por água subterrânea: Diagnóstico do município de Nísia Floresta. Recife: Ministério de Minas e Energia, 2005b. 32 p.

Moura, N. F.; Moura, M. F.; Pereira, M. De F.; Chaves, L. J. Diversidade genética e variação fenotípica de caracteres morfológicos em mangaba (Hancornia speciosa Gomes). In: SIMPÓSIO NACIONAL DO CERRADO E II SIMPÓSIO INTERNACIONAL SAVANAS TROPICAIS, 9., 2008, Brasília. Anais eletrônicos... Brasília: Embrapa, 2008. p. 1 - 7. Disponível em: <http://www.cpac.embrapa.br/publicacoes/search_pbl/1?q=Variação genética>. Acesso em: 25 nov. 2013.

Silva, M. S.; Vieira, F. A.; Carvalho, D. Biometria dos frutos e divergência genética em uma população de Geonoma schottiana Mart. Revista Brasileira de Biociências (Impresso), v. 5, p. 582-584, 2007.

STATSOFT, INC. 2004. STATISTICA (data analysis software system). Version 7. www.statsoft.com.

Tabarelli, M.; Vicente, A.; Barbosa, D. C. A. Variation of seed dispersal spectrum of woody plants across a rainfall gradient in northeastern Brazil. Journal of Arid Environments, p. 197-210. fev. 2003.

Vieira, F. A.; Carvalho, D. de. Maturação e morfometria dos frutos de Miconia albicans (Swartz) Triana (Melastomataceae) em um remanescente de Floresta Estacional Semidecídua Montana em Lavras, MG. Revista Árvore, v. 33, p.1015-1023, 2009.

Zuffo, A. M; Gonçalves, L. G. V; Andrade, F. R.; Souza, T. R. S.; Marimon-Junior, B. H. Biometria de sementes de mangaba (Hancornia speciosa Gomes). In: IV ENAAG - ENCONTRO AMAZÔNICO DE AGRÁRIAS, 4, 2012, Belém. Biometria de sementes de mangaba (Hancornia speciosa Gomes). Belém: Anais do Encontro Amazônico de Agrárias, 2012. 